\title{
Efficacy of plant growth regulators on growth characters and yield attributes in brinjal (Solanum melongena L.) cv. Brinjal 3112
}

\author{
Janak Lal Netam ${ }^{1}$ and Richa Sharma ${ }^{2}$ \\ 1, 2 (Department of Biological Sciences, Sam Higginbottom Institute of Agriculture, Technology and Sciences, \\ Allahabad-211007, U.P. India)
}

\begin{abstract}
The experiment was carried out during kharif season 2013, Department of Biological Sciences, Sam Higginbottom Institute of Agriculture, Technology and Sciences, Allahabad, Uttar Pradesh.The efficacy of different Plant growth regulators and their and their combination of naphthalene acetic acid (NAA), gibberellic acid $\left(G_{3}\right)$ and dichlorophenoxyacetic acid $(2,4-D)$ spray on fruit yield and quality in brinjal and the crop selected for the experiment was one brinjal variety Brinjal 3112 with three replicants. Plants were sprayed three times at 30, 60 and 90 days after transplanting. The highest plant height, number of leaves, plant fresh weight and plant dry weight was observed and ascorbic acid estimated for GA 350 ppm. The highest number of branches, number of fruits, fresh fruit weight was observed and total soluble solid, nitrate reductase activity was recorded by the treatment combination of $A_{3} @ 10$ ppm,NAA@20 ppm. The combined application of GA $A_{3}$, NAA and 2,4-D significantly increased vegetative growth, yield and quality of brinjal compared with control. Based on the results, it can be concluded that combined application of GA, NAA and 2,4-D@10 ppm, 20 ppm and 1 ppm of 2,4-D had significantly on plant growth, flowering, quality and yield potential.
\end{abstract}

Key Words: Gibberellic acid, 2,4-dichlorophenoxy acetic acid, Naphthalene acetic acid, Brinjal (Solanum melongena L.), growth, quality.

\section{Introduction}

Brinjal (Solanum melongena L., $2 \mathrm{n}=2 \mathrm{x}=24$ ) is a widely adaptive and highly productive vegetable crop of tropical and subtropical regions world, which suffers from various abiotic and biotic stresses (Kaur et $a l ., 2004)$. It is one of the most popular vegetable crops in many parts of the world including India. The crop is cultivated on small family farms and considered to be important source of nutrition and cash income for many resource poor farmers (Bose et al., 1993). The brinjal is of much importance in the warm areas of Far East, being grown extensively in India, Bangladesh, Pakistan, China and the Philippines. In India, it is one of the most common, popular and principal vegetable crops grown throughout the country except higher altitudes. It is a versatile crop adapted to different agro-climatic regions and can be grown throughout the year. It is a perennial but grown commercially as an annual crop. A number of cultivars are grown in India, consumer preference being dependent upon fruit color, size and shape (Gopalan et al., 2007). The fruits are known for being low in calories and having a mineral composition beneficial for human health. They are also rich source of Potassium, Magnesium, Calcium and Iron (Zenia et al., 2008). Plant growth regulators like promoters, inhibitors or retardants play a key role in controlling internal mechanisms of plant by interacting with key metabolic processes such as, nucleic acid metabolism and protein synthesis. Use of the growth regulators (PGRs) might be a useful alternative to increase crop production. Recently, there has been global realization of the important role of PGR's in increasing crop yield. Gibberellic acid is an important growth regulator that may have many uses to modify the growth, yield and yield contributing characters of plant (Rafeekher et al. 2002). Plant growth regulators are used widely to improve plant performance. Gibberellic acid is one of those growth regulators that have positive effect on plant growth through the effect on cell division and elongation (Batlang et al., 2006). It recorded dipping of brinjal seedling roots in NAA at 0.1 or $0.2 \mathrm{ppm}$ for 24 hours influenced growth and development (Sambasiva Rao et al. 1980). Brinjal is known to have ayurvedic medicinal properties and is good for diabetic patients. It has also been recommended as an excellent remedy for those suffering from liver complaints (Shukla and Naik 1993). This study was therefore initiated to investigate the best dose of the PGRs under consideration in single or combined application that improve brinjal fruit yield and quality.

\section{Material And Methods}

The experiment was carried out during kharif season 2013 on Department of Biological Sciences, Sam Higginbottom Institute of Agriculture, Technology and Sciences, Allahabad, (U.P.). The experiment consisted of three levels of gibberellic acid, two levels of naphthalene acetic acid and two levels of 2,4dichlorophenoxyacetic acid and their combinations arranged in randomized block design with three replications 


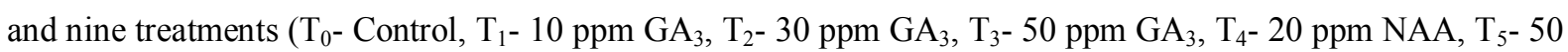
ppm, $\mathrm{T}_{6^{-}} 1$ ppm 2,4-D, T $7^{-} 2$ ppm 2,4-D and $\mathrm{T}_{8^{-}}$combinations of $\mathrm{GA}_{3}$, NAA, 2,4-D@10 ppm, 20 ppm and 1 ppm of 2,4-D). The required weight of the PGRs was taken using electronic sensitive balance and solution was prepared by dissolving in $1 \mathrm{mg} \mathrm{L}^{-1}$. The solution was poured into hand-held sprayer and was directly sprayed on the plants three times at 30,60 and 90 days after transplanting. Spraying was performed early in the morning to avoid rapid drying of the spray solution, due to transpiration. Data were collected from selected plants in the rows. The collected data includes average plant height $(\mathrm{cm})$, number of leaves/plant, number of branches/plant, number of fruits/plant, fresh fruit weight (g/plant), protein $(\mathrm{mg} / \mathrm{g})$ and ascorbic acid $(\mathrm{mg} / 100 \mathrm{~g})$, . The data was analyzed using analysis of variance (ANOVA) by software and mean separation was carried out at $5 \%$ probability level.

\section{Result And Discussion}

\subsection{Obsevation on growth parameters}

\subsubsection{Plant Height (cm)}

At 30 DAT maximum plant height was found in $\mathrm{T}_{3}$ (40.13) followed by $\mathrm{T}_{8}(37.63)$ and minimum was found in $\mathrm{T}_{0}(20.10)$, at 60 DAT maximum plant height in $\mathrm{T}_{3}(54.30)$ followed by $\mathrm{T}_{8}(52.07)$ and minimum was found in $\mathrm{T}_{0}$ (34.24). At 90 DAT maximum plant height was found in $\mathrm{T}_{3}$ (76.10) followed by $\mathrm{T}_{8}(74.27)$ and minimum was found in $\mathrm{T}_{0}$ (46.73). Gibberellin can promotes the activity of xyloglucan endotransglycosylase (XET) which cause loosening of cell wall and increase cell permeability (Saptari and Dawi 2013). Similar result was found in brinjal by Meena and Dhaka (2003).

\subsubsection{Number of leaves}

At 30 DAT maximum number of leaves was found in $\mathrm{T}_{3}(24.73)$ followed by $\mathrm{T}_{8}(22.46)$ and minimum was found in $\mathrm{T}_{0}$ (16.31), at $60 \mathrm{DAT}$ maximum number of leaves was found in $\mathrm{T}_{3}(53.26)$ followed by $\mathrm{T}_{8}(52.18)$ and minimum was found in $\mathrm{T}_{0}$ (41.53). At 90 DAT maximum number of leaves was found in $\mathrm{T}_{3}(94.27)$ followed by $\mathrm{T}_{8}(93.46)$ and minimum was found in $\mathrm{T}_{0}$ (70.14). Similar result was found in tomato by Gabal et al. (1999).

\subsubsection{Number of branches}

At 30 DAT maximum number of branches was found in $\mathrm{T}_{8}$ (8.90) and minimum was found in (4.60), at 60 DAT maximum number of branches was found in $\mathrm{T}_{8}$ (22.90) and minimum was found in $\mathrm{T}_{0}$ (11.38). At 90 DAT maximum number of branches $\mathrm{T}_{8}(25.80)$ and minimum was found in $\mathrm{T}_{0}$ (17.36). Similar result was found in chilli by Gollagi (1999) and tomato by Mehta et al. (1989).

\subsection{Observation on physiological parameters \\ 3.2.1 Ascorbic acid}

Ascorbic acid maximum was found in $\mathrm{T}_{3}(2.56 \mathrm{mg})$ and minimum was found in $\mathrm{T}_{0}(1.51 \mathrm{mg})$. The augment of ascorbic acid with $\mathrm{GA}_{3}$ treatment might be either due to encouragement of biosynthesis of ascorbic acid or protection of synthesized ascorbic acid from oxidation through the enzyme ascorbic acid oxidase and gibberellin may promote the activity of acid invertase which causing an increase in hexose level in plant tissue as was reported in chilli by Saptari and Dewi (2013) and Chattopadhyay and Sen (1974) and Desai et al. (1993) in chilli.

\subsubsection{Nitrate reductase activity}

At 30 DAT maximum nitrate reductase activity was found in $\mathrm{T}_{8}(41.30)$ and minimum was found in $\mathrm{T}_{0}$ (27.80), at 60 DAT maximum nitrate reductase activity was found in $\mathrm{T}_{8}(124.20)$ and minimum was found in $\mathrm{T}_{0}$ (74.60). At 90 DAT maximum nitrate reductase activity was found in $\mathrm{T}_{3}(107.50)$ and minimum was found in $\mathrm{T}_{0}$ (61.80). These growth regulators may have affected activity and thereby increasing supply of reduced nitrogen to support growth. Nitrate reductase, a key enzyme in control of nitrogen assimilation is target of several regulatory processes. Relationships between auxins and nitrate reductase have been reported by Vuylsteker et al. (1998).

\subsection{Yield parameters}

\subsubsection{Number of fruits}

Maximum number of fruits/plant was found in $\mathrm{T}_{8}$ (18.83) and minimum was found in $\mathrm{T}_{0}(9.31)$. Exogenous supply of growth regulators at critical stages of flowering and fertilization, ovary formation, fruit and seed development period etc. may enhance source to sink relationship, accumulation of photosynthates and efficient utilization of food reserves for the development of fruit. These results are supported by the findings of Mehta et al. (1989) in chilli. 


\subsubsection{Fruit weight per plant}

Maximum fresh fruit weight/plant $(\mathrm{kg})$ was found in $\mathrm{T}_{8}(3.67 \mathrm{~kg})$ and minimum was found in $\mathrm{T} 0(1.26$ $\mathrm{kg}$ ). The tomato plants exhibited improvements relevant to growth, sustainable health and enhancement in flowering \& fruit parameters in such a coordinated manners for collective contribution toward the higher weight of fruit. These results are in confirmation with reported findings Sumiati, (1987) and Edison (1991) in tomato and Pampapathy and Rao (1975) in brinjal.

Table 1. Efficacy of plant growth regulators on growth parameters at different stages in Brinjal.

\begin{tabular}{|c|c|c|c|c|c|c|c|c|c|}
\hline \multirow{2}{*}{ Treatments } & \multicolumn{3}{|c|}{ Plant Height $(\mathrm{cm})$} & \multicolumn{3}{c|}{ Number of leaves/plant } & \multicolumn{3}{c|}{ Number of branches/plant } \\
\cline { 2 - 10 } & $30 \mathrm{DAT}$ & 60DAT & 90DAT & 30DAT & $60 \mathrm{DAT}$ & 90DAT & 30DAT & 60DAT & 90DAT \\
\hline $\mathrm{T}_{0}$ & 20.10 & 34.24 & 46.73 & 16.31 & 41.53 & 70.14 & 4.60 & 11.38 & 17.36 \\
\hline $\mathrm{T}_{1}$ & 25.80 & 40.30 & 60.71 & 18.24 & 47.10 & 85.48 & 6.90 & 20.42 & 21.27 \\
\hline $\mathrm{T}_{2}$ & 28.90 & 44.42 & 62.24 & 19.78 & 50.13 & 87.10 & 7.30 & 21.50 & 22.53 \\
\hline $\mathrm{T}_{3}$ & 40.13 & 54.30 & 76.10 & 24.73 & 53.26 & 94.27 & 8.34 & 22.70 & 24.32 \\
\hline $\mathrm{T}_{4}$ & 28.18 & 42.10 & 62.31 & 18.86 & 47.90 & 86.08 & 6.74 & 20.23 & 23.60 \\
\hline $\mathrm{T}_{5}$ & 36.24 & 48.62 & 69.20 & 21.31 & 50.77 & 90.16 & 7.60 & 21.80 & 24.12 \\
\hline $\mathrm{T}_{6}$ & 29.02 & 43.14 & 66.18 & 17.23 & 46.36 & 85.30 & 5.10 & 17.30 & 20.50 \\
\hline $\mathrm{T}_{7}$ & 37.45 & 51.02 & 68.32 & 19.12 & 48.68 & 86.92 & 6.40 & 21.24 & 23.52 \\
\hline $\mathrm{T}_{8}$ & 37.63 & 52.07 & 74.27 & 22.46 & 52.18 & 93.46 & 8.90 & 22.90 & 25.80 \\
\hline $\mathrm{F}-\mathrm{test}$ & $\mathrm{S}$ & $\mathrm{S}$ & $\mathrm{S}$ & $\mathrm{S}$ & $\mathrm{S}$ & $\mathrm{S}$ & $\mathrm{S}$ & $\mathrm{S}$ & $\mathrm{S}$ \\
\hline $\mathrm{S} . \mathrm{Ed}( \pm)$ & 0.076 & 0.083 & 0.058 & 0.086 & 0.075 & 0.078 & 0.077 & 0.294 & 0.348 \\
\hline $\mathrm{CD}(5 \%)$ & 0.156 & 0.171 & 0.119 & 0.178 & 0.156 & 0.160 & 0.159 & 0.608 & 0.719 \\
\hline
\end{tabular}

Table 2. Efficacy of plant growth regulators on physiological and yield parameters at different stage in Brinjal.

\begin{tabular}{|c|c|c|c|c|c|c|}
\hline \multirow[t]{2}{*}{ Treatments } & \multirow{2}{*}{$\begin{array}{l}\text { Number of } \\
\text { fruits/plant }\end{array}$} & \multirow{2}{*}{$\begin{array}{l}\text { Fruits weight } \\
\text { (kg/plant) }\end{array}$} & \multirow{2}{*}{$\begin{array}{c}\text { Ascorbic } \\
\text { acid(mg/100g) }\end{array}$} & \multicolumn{3}{|c|}{ Nitrate reductase activity $\left(\mu \mathrm{mol} \mathrm{NO}_{2} / \mathrm{g} \mathrm{fw} / \mathrm{hr}\right)$} \\
\hline & & & & 30DAT & 60DAT & 90DAT \\
\hline $\mathrm{T}_{0}$ & 9.31 & 1.26 & 1.51 & 27.80 & 74.60 & 61.80 \\
\hline $\mathrm{T}_{1}$ & 12.60 & 1.55 & 1.89 & 35.70 & 90.40 & 84.40 \\
\hline $\mathrm{T}_{3}$ & 16.32 & 2.06 & 2.56 & 40.30 & 106.40 & 95.30 \\
\hline $\mathrm{T}_{4}$ & 14.30 & 1.83 & 1.77 & 38.60 & 95.80 & 86.70 \\
\hline $\mathrm{T}_{7}$ & 17.30 & 3.05 & 1.92 & 37.80 & 95.30 & 85.40 \\
\hline $\mathrm{T}_{8}$ & 18.83 & 3.67 & 2.34 & 41.30 & 124.20 & 107.50 \\
\hline F-test & $\mathrm{S}$ & $\mathrm{S}$ & $\mathrm{S}$ & $\mathrm{S}$ & $\mathrm{S}$ & $\mathrm{S}$ \\
\hline S.Ed( $( \pm)$ & 0.076 & 2.40 & 0.078 & 0.502 & 0.792 & 0.136 \\
\hline $\mathrm{CD}(5 \%)$ & 0.157 & 4.97 & 0.160 & 1.036 & 61.636 & 0.281 \\
\hline
\end{tabular}

\section{CONCLUSION}

Results showed that foliar spray of plant growth regulators not only increased the vegetative growth and fruits but also enhanced the yield and quality of brinjal cv. "Brinjal- 3112". On the basis of one trial experiment, it is concluded that combined application of $\mathrm{GA}_{3}$ (Gibberellic acid -10 ppm) with NAA (Naphthalene acetic acid-20 ppm) and 2,4-D (2,4-Dichloro phynoxy actic acid- $1 \mathrm{ppm})$ showed positively significant effect on growth, yield and physiological parameters (Ascorbic acid and Nitrate reductase activity) of brinjal.

\section{Acknowledgements}

I great thankful to my advisor Mrs. Richa Sharma, my mother Pramila Netam, and my whole family members and my Best Friend Pramod Choudhary for their guidance, inspiring, co-operation, encouragement during the preparation of this manuscript.

\section{References}

[1]. Batlang, V., Emongor, V.E. and Pule-Meulenburg, F., 2006. Effect of benzyladenine and gibberellic acid on yield and yield components of cucumber (Cucumis sativus L. cv. ' tempo' ). J. Agron., 5(3): 418-423.

[2]. Chattopadhyay T. K., and Sen S. K., 1974. Studies on the effect of different growth regulators on reproductive physiology and morphology of chilli (Capsicum annuum L.). Veg. Sci. 1: 42-45.

[3]. Desai B. B., Patil V. B., and Chayan U. D., 1993. Effects of synthetic plant growth regulators on the chemical composition of some promising chilli cultivars. J. Maharastra Agri. Univ. 18 (2): 292-293.

[4]. Edison, H. S., 1991. The effect growth regulators IAA on the development of tomato fruits cv. Ratna Balai. Penelitian Hortikulatura. Solok Hortura 30: 9-11.

[5]. Gabal, Oben G. M. and Gareell, R., 1999. Effect of GA on morph physiological characters and yield of kidney beans (Phaseiolus valgaris). J. Agron. Crop. Sci., 160(2): 91-101.

[6]. Gollagi, S. G., 1999. Influence of growth regulators and nutrients for increasing productivity potential and quality in chilli (Capsicum annuum L.). M.Sc.(Agri.) Thesis, Uni. Agric. Sci., Dharwad (India). 
[7]. Gopalan, C., Rama Sastri, B.V. and Balasubramanian, S., 2007. Nutritive Value of Indian Foods, published by National Institute of Nutrition (NIN), ICMR.

[8]. Kaur, S., Bal, S. S., Singh, G., Sidhu, A. S., Dhillon, T. S., 2004. Management of brinjal shoot and fruit borer, Leucinodes orbonalis Guenee through net house cultivation. Acta Hortic. 659:345-350.

[9]. Meena S.S., and Dhaka R.S., 2003, Economics of plant growth regulators in brinjal (Solanum melogena L.) under semiarid condition of Rajasthan. Annals Agric. Res., 24 (2): 273-275.

[10]. Mehta, A. K., Singh, R. P. and Lal, G., 1989. Effect of concentration and methods of application of 2,4-D phenoxy acetic acid on yield, fruit quality and seed quality of tomato (Lycopersicon esculentum Mill). Veg. Sci., 16 (1): 1-8.

[11]. Pampapathy, K. and Rao S. N., 1975. Studies on the effect of GA and 2,4-D on yield and quality of brinjal (solanum melongene L.). Andhra Agric.J., 23 (1\&2): 53-58.

[12]. Rafeekher, M., Nair, S. A., Sorte, P. N., Hatwal, G. P. and Chandhan, P. M., 2002. Effect of growth regulators on growth and yield of summer cucumber. J. Soils Crops, 12 (1): 108-110.

[13]. Sambasiva Rao, G., D. U. S. Rao and Surayanarayana V., 1980. Effect of starters and naphthalene acetic acid in brinjal. Veg. Sci. 7: $129-132$.

[14]. Saptari R.T., and Dewi K., 2013, Effect of borax and gibberellic acid on the growth and development of red chilli (Capsicum annuum L. "gelora"). The Third Basic Science International Conference. (B41):1-3.

[15]. Shukla, V. and Naik, L. B., 1993. Agro-techniques of solanaceous vegetables, in 'Advances in Horticulture', Vol. 5, Vegetable Crops, Part 1 (K. L. Chadha and G. Kalloo, eds.), Malhotra Pub. House, New Delhi, p. 365.

[16]. Sumiati, E., 1987. Effect of plant growth regulators on flowering and yield of tomatoes in the Lembang Highlands. Bull. Pene. Hortic., 15 (1): 134-143.

[17]. Vuylsteker, C., Prinsen, E., Boutin, J., Onchelen, H. V. and Rambour, S., 1998. Evidence for nitrate reductase expression during initiation of lateral roots by NAA in chicory. J. Exp. Bot. 49: 937-944.

[18]. Zenia, M. and Halina, B., 2008. Content of micro elements in Egg plant fruits depending on Nitrogen fertilization and plant training method. Journal of Elementology, 13 (2):269-275.

[19]. Bose, T. K., Some M. G., and Kabir, K., 1993, Vegetable crops, $2^{\text {nd }}$ edn.(Noya Prokash, Kalyani, India) 281. 